\title{
Türkiye'nin En Değerli Markalarının Sponsorluk Faaliyetleri: Dijital Bir Mecra Olan Kurumsal Web Sayfaları Üzerine Bir Analiz
}

\author{
Turkey's Most Valued Brands Sponsorship Activities: \\ An Analysis On Corporate Web Pages As A Digital Medium
}

\author{
Özer Silsüpür, Öğr. Gör. Dr., Trabzon Üniversitesi İletişim Fakültesi, E-posta: ozer.silsupur@gmail.com \\ İsmail Kocabaş, Dr. Öğr. Üyesi, İstanbul Rumeli Üniversitesi Sanat ve Tasarım Fakültesi, E-posta: kcbs.ismail@gmail.com
}

https://doi.org/10.47998/ikad.972855

Anahtar Kelimeler:
Sponsorluk,
Dijital Mecra,
Kurumsal Web
Sayfaları,
Türkiye'nin En Değerli
Markaları,
İçerik Analizi.

İçerik Analizi.

Keywords:

Sponsorship, Digital Medium, Corporate Web Pages,

Turkey's Most Valued Brands, Content Analysis.

Araştırmacı Orcid ID

Geliș Tarihi

Kabul Tarihi
$\ddot{\mathbf{O} z}$

Markalar, tanınırlıklarını artırmak, marka imajlarını desteklemek, marka kimliklerini pekiştirmek, medyanın ilgisini çekmek gibi amaçlarla sponsorluk faaliyetleri gerçekleştirmekte ve bu sponsorluk çalışmalarının da hedef kitlelere duyurulmasında dijital araç olan kurumsal web sayfalarından yararlanmaktadırlar. Bireylerin markalarla ilgili bilgi arayışında başvurduğu öncelikli dijital mecralar arasında yer alan kurumsal web sayfaları, markalar için vitrin niteliği taşımaktadır. Bu bağlamda çalışmada, Brand Finance 2021 raporuna göre, "Türkiye'nin En Değerli Markalar" sıralamasında yer alan ilk 10 marka ve onların sponsorluk çalışmaları kurumsal web sayfaları üzerinden analiz edilmiş̧ir. $\mathrm{Bu}$ amaçla Türkiye'nin En Değerli ilk 10 markasının web sayfalarında, sponsorluk çalışmalarına ilişkin mesajlara yer verilip verilmediği, mesajların hangi iletişim biçimiyle duyurulduğu, paylaşılan mesajların hangi sponsorluk alanlarına yönelik gerçekleştirildiği, sponsorluk mesajlarının web sayfalarının neresinde yer aldığı gibi amaçlar çerçevesinde 02.07.202116.07.2021 tarihleri arasında içerik analizi yöntemiyle incelenmiş ve sonuçlar ortaya konulmuştur. Buna göre, Türkiye'nin En Değerli ilk 10 markasından 6'sının kurumsal web sayfasında "Sponsorluk" linkinin olmadığı belirlenmiştir. Türk Hava Yolları hariç, diğer markaların sponsorluk mesajlarını "Sponsorluk ve Sosyal Sorumluluk" başlığı altında paylaştıkları görülmüştür. Markaların en çok kültür/sanat ve spor alanlarında sponsorluk faaliyetinde bulundukları ve en fazla ana sponsor düzeyinde destek oldukları sonucuna ulaşılmıştır. Markalar sponsorluk mesajlarını en çok, görsel ve yazılı materyal, metin ve basın bülteni olarak web sayfalarında paylaşmışlardır.

\section{Abstract}

Brands conduct sponsorship activities for various purposes like increasing recognition, supporting image of the brand, reinforcing identity of the brand and attracting media's attention benefiting from corporate web pages which is an important digital tool to announce activities. Corporate web pages, which are among the primary digital channels that individuals apply in search of information about brands, are a showcase for brands. Considering Brand Finance 2021 report, sponsorship activities of Turkey's Top 10 Most Valuable Brands were selected and brands corporate web pages were examined by content analysis method between 02.07.2021-16.07.2021. The results of the objectives were revealed, whether messages related to sponsorship activities are included on the web pages, communication form of messages, intended sponsorship area of shared messages and where sponsorship messages are located in web pages. Total 6 out of 10 most valuable brands do not have "Sponsorship" links in their corporate pages. Besides Turkish Airlines, other brands share sponsorship messages in "Sponsorship and Social Responsibility" title. Brand mostly sponsoring culture/art, sport activities and support it at the level of the main sponsor. Brands mostly shared their sponsorship messages on web pages as visual and written materials, texts and press releases.

\footnotetext{
: 1: 0000-0002-2965-2235, 2: 0000-0003-4833-9700

: 18.07 .2021

: 08.09.2021
} 


\section{Giriş}

Sponsorluk, kurumsal imajın geliştirilmesi ve marka bilinirliğinin artırılması gibi kurumsal hedefleri desteklemek amaciyla etkinliklere yapılan yatırımlar olarak tanımlanmaktadır (Gardner ve Shuman, 1988: 44). Halkla ilişkiler uygulamalarından olan sponsorluk, yeni iş firsatları yakalamak, markaların görünürlügünü artırmak (Renard ve Sitz, 2011: 126), çalışanların moralini güçlendirmek, yeni çalışanlar kazanmak, sadık müşteriler elde etmek, marka imajını geliştirmek ve toplumda iyi niyet oluşturmak (Javalgi vd., 1994: 48) gibi çeşitli faydalar sağlamaktadır. Markaların gerçekleştirdiği sponsorluk faaliyetleri, hedef kitleler nezdinde markalara pozitif anlam vermenin en iyi yoludur. Sponsorluk, markaya maruz kalma ve onun olumlu deneyimleriyle ilişkilendirerek hedeflere ulaşmada önemli bir araçtır (Renard ve Sitz, 2011: 122). Ancak bu noktada marka tarafından gerçekleştirilen sponsorluk faaliyetlerinin hedef kitle ve topluma duyurulması sorunu ortaya çıkmaktadır. Geleneksel iletişim araçları, yapılan faaliyetlerin duyurulmasında önemli katkılar sunmakla beraber, yeni Dijital Çağ'ın getirileriyle daha fazla kişiye bilgiyi ulaştırma ve duyurma konusunda dijital mecralar ön plana çıkmaktadır.

Kurumsal web sayfaları, markanın kendisi hakkında haber bültenleri sunması, insanların araştırma yapabilmesine fırsat sunması ve kurumsal bilgilerin yayılması gibi halkla ilişkiler amaçlarına hizmet etmektedir (Kent ve Taylor, 1998: 322). Özellikle toplumda iyi niyet ve olumlu imaj oluşturma gayesindeki markalar, web sayfaları aracılığıyla sponsorlukları hakkında haber verme, duyurum ve bilgilendirme (Sever, 2013: 95) yapmaktadırlar. Web sayfaları, markaların halkla ilişkiler faaliyetlerinin zaman-mekân kısıtlaması gibi bir engeli aşarak duyurulmasına imkân sunan bir araçtır. Bu gibi özelliklere sahip olması nedeniyle markalar, kendileri hakkında hedef kitlelere yönelik sunmak istedikleri enformasyonun yanı sıra gerçekleştirdikleri birçok faaliyeti web sayfaları üzerinden duyurma yolunu seçmektedirler (Gürbüz ve Tarhan, 2019: 538). Markaların gerçekleştirdikleri faaliyetlerin nasıl, nerede, hangi başlık altında sunulduğu ise, ona atfettikleri önemi göstermesi açısından önemli ipuçları vermektedir.

Markaların sponsorluk faaliyetlerini web sayfalarından nasıl sunduklarını ortaya koyan sınırlı sayıda araştırma olması nedeniyle, Brand Finance 2021 raporuna göre, Türkiye'nin En Değerli ilk 10 markasının sponsorluk faaliyetleri, kurumsal web sayfaları üzerinden 02.07.2021-16.07.2021 tarihleri arasında içerik analizi tekniği kullanılarak araştırılmıştır. Araştırmada, farklı sektörlerde yer alan markaların sponsorluk faaliyetleri kapsamında hangi alana katkı sunduğu, üstlenilen sponsorluk türleri, sponsorluğa ilişkin mesajlarını iletme biçimleri, sponsorluğa ilişkin mesajlarını kurumsal web sayfasının neresinde ve hangi başlıklar altında sundukları, gerçekleştirilen sponsorluklara yönelik desteklerinin boyutu ve kapsamı gibi hususlar üzerine karşılaştırmalı bir analiz yapılmıştır.

\section{Halkla İlişkiler Araçlarından Sponsorluk}

Sponsorluk, bir faaliyet, kişi ya da işletmenin ticari potansiyelinden yararlanmak amacıyla sponsor tarafından hizmet veya ayni yapılan yardım olarak tanımlanabilmektedir. Diğer taraftan sponsorluk, bir markanın/işletmenin çeşitli organizasyon/etkinlik ya da 
olaylara ilişkin yatırım gerçekleştirerek markasını dolaylı yoldan tanıtmasıdır (Ateşoğlu, 2010: 180). Sponsorluk faaliyetleri, markaların ismini duyurmada etkili olan reklam ve tanıtım hedeflerinin yanı sıra, kamuoyu yararı ön plana alınarak saygınlığı geliştirmek, topluma hizmet sunmak amaciyla da gerçekleştirilen faaliyetlerdir (Aydede, 2002: 169). İki yönlü bir ilişkinin gerçekleştiği halkla ilişkiler, sponsorluk gibi planlı ve hedef kitleye ilişsin uzun süreçli amaçlara ulaşma gayesini taşımaktadır (Coşkun, 1999: 65). Sponsorluk ile halkla ilişkiler arasındaki ilişkiye bakıldığında sponsorluk; tanıtım faaliyetleri, kurum imajına katkı sağlama, kurumsal kimliği destekleme, farkındalık oluşturma gibi amaçların yanı sıra, hedef kitlenin satın alma, tutum ve davranışlarına yön vermede de halkla ilişkileri destekleyici bir uygulama olması nedeniyle kurumlar tarafından oldukça fazla kullanılmaktadır (Canöz ve Doğan, 2015: 20). Ayrıca halkla ilişkiler uygulamalarından birisi olan sponsorluk, marka farkındalığı, marka sadakati, marka imajı ve marka çağrışımlarını oluşturmasıyla, markanın hedef kitle nazarında algılanan kalitesinin geliştirilmesinde önemli bir unsurdur (Kürkçü, 2015: 1). Markalar hedeflerine ulaşmak için sponsorluk faaliyetlerini, karşılıklı iletişimi ve ilişkiyi geliştirme işlevlerinden dolayı kurumsal web sayfaları aracılığıyla duyurmaktadır (Chiou vd., 2010: 282). Dolayısıyla markalar, halkla ilişkiler uygulamalarından olan sponsorluk faaliyetlerinin duyurulması ve neticesinde erişilmek istenen hedeflere ulaşmada kurumsal web sayfalarının kullanımı önem arz etmektedir.

\section{Sponsorluğun Gerçekleştirilme Amaçları}

Markaların sponsorluk faaliyetlerini gerçekleştirme amaçlarına bakıldığında; iyi niyet oluşturma, marka bilinirliğini artırma, tüketici algılarını değiştirme, tüketicileri ikna etme (Amoako vd., 2012: 78), kurumun hedef kitle tarafindan benimsenmesini sağlama, kurum kimliğini destekleme ve kuruma ilişkin pozitif imaj oluşturma gibi nedenler olduğu görülmektedir. Bunlardan kurumsal imaj oluşturma ya da hâlihazırdaki imaj1 desteklemek, sponsorluğun gerçekleştirilmesinde öncelikli sebepler arasında yer almaktadır (Canöz ve Doğan, 2015: 34).

Markaların sponsorluk amaçlarını halkla ilişkiler, reklam ve pazarlama olarak üç ana kategoride verebilmek mümkündür (Okay, 2012: 64-97):

Sponsorluğun Halkla İlişkiler Amaçları: Kurum kimliğini pekiştirmek, marka veya kuruluşun tanınırlığını artırmak, toplumun iyi niyetini kazanmak, marka veya kurum imajını desteklemek, çalışanların motivasyonunu artırmak, medyanın ilgisini çekmek ve kurum içi ilişkileri geliştirmek.

Sponsorluğun Reklam Amaçları: Radyo ve televizyonda reklamı yasak olan ürünleri duyurmak, başka reklam olanaklarını kullanmak ve ürünleri desteklemek.

Sponsorluğun Pazarlama Amaçları: Bir ürünü tanıtmak, bir ürünü piyasaya yerleştirmek, ürün kullanımını desteklemek, müşteri sadakatini artırmak, pazarlama politikasında değişiklik oluşturmak ve uluslararası pazarlama faaliyetleri gerçekleştirebilmek.

Markalar, kurumsal amaçlarına ulaşmak için farklı düzeylerde ve farklı alanlara yönelik çeşitli sponsorluk faaliyetleri gerçekleştirmektedirler. 


\section{Sponsorluk Düzeyleri}

Sponsorluk faaliyetleri yapılma düzeyleri ve kapsamları itibariyle farklılıklar içeren uygulamalardandır (Lucas, 2015: 12). Bu nedenle de "Ana Sponsor" ve "Yan Sponsor" olarak ikiye ayrılmaktadır.

Ana Sponsor: Yapılan katkı ve tür bakımından asıl (Öztürk, 2013: 11) ve en yüksek desteği veren kuruluşlar ana sponsor olarak adlandırılmaktadır (Amoako vd., 2012: 68). Ana sponsor, yan sponsorluğa göre çeşitli açılardan daha fazla kullanım hakkını elde etme anlamına da gelmektedir. Özellikle bir dünya futbol şampiyonası gibi büyük olaylarla ilgili olarak, ana sponsor kıyafetlerinin markalanmasından farklı mecralarda ve zaman dilimlerinde isminin yer almasına ve hatta spor mekanının seçimine kadar daha geniş bir çerçevede söz sahibi olabilmektedir (Lucas, 2015: 12-13). Ana sponsorluğu üstlenen kuruluşlar, basıl1-görsel her türlü materyal ve medyada logo ve isimleriyle yer alabilme, hem iç hem de dış hedef kitlesine yönelik olanaklar sunma, ürün/hizmetlerini tanıtabilme ve resmi destekleyici unvanını belli bir süreliğine kullanabilme gibi bir takım beklentilerle ana sponsorluk gerçekleştirmektedir (MEB, 2011: 22).

Yan Sponsor: Ortak sponsorluk olarak da adlandırılan yan sponsorluk bir kuruluş için yalnızca belirli bir ürün alanına yönelik (örneğin resmi bir telekomünikasyon sponsoru olarak) belirli seviyedeki sınırlı hakları satın alma hakkını elde etmektir (Lucas, 2015: 12-13). Bir televizyon programından herhangi bir etkinlik ya da spor faaliyetine kadar, organizasyonun başlangıç veya sonunda ya da belirli kısa bir zaman dilimi ve pozisyonda, doğrudan ekonomik veya ürün/hizmet ve teçhizat gibi materyallerle daha küçük çapta (Cornwell, 2020: 23), daha az para harcayarak destek olan kuruluşun sponsorluğu, yan sponsorluk olarak adlandırılmaktadır (Öztürk, 2013: 11). Yan sponsorluğu üstelenen kuruluşlarda ana sponsorlar gibi basın toplantısında/panolarda yer alma, kendi reklamını ortaya koyabilme, kendi gösterilerini düzenleyebilme ve logolarına yer verilmesi gibi beklentilerle sponsorluk faaliyetini ortaya koymaktadır (MEB, 2011: 22).

\section{Sponsorluk Çeşitleri}

Sponsorluklar hem yapılma düzeylerine hem de yapıldı̆̆ 1 alana göre çeşitlere ayrılmaktadır. Oliver (2004: 190), çalışmasında spor sponsorluğu, müzik ve sanat sponsorluğu ve diğer eğlence aktivitelerine yönelik sponsorluk; Okay (2013: 108), spor sponsorluğu, kültür-sanat sponsorluğu, çevre sponsorluğu ve sosyal sponsorluk; Peltekoğlu (2014: 384-394), spor sponsorluğu, kültür-sanat sponsorluğu, çevre sponsorluğu ve sosyal sponsorluk ve Akkaya'nın (2016: 813), önceki araştırmacıların sınıflandırmasına ek olarak bilimsel araştırma ve eğitim sponsorluğuna da yer verdiği görülmektedir. $\mathrm{Bu}$ çalışmada da spor sponsorluğu, sosyal/çevre sponsorluğu, eğitim sponsorluğu ve kültürsanat sponsorluğuna (Gürbüz ve Tarhan, 2019: 544-546) yönelik bilgilere yer verilecektir.

Spor Sponsorluğu: Günümüzde kuruluşların ve markaların en fazla tercih ettikleri sponsorlukların başında \%32'lik oranla spor sponsorluğu gelmektedir (Gürbüz ve Tarhan, 2019: 555). Özellikle çağımızda sporun bir endüstriye dönüşmesi (Tekin ve Eskicioğlu, 2015: 15) ve evrensel bir dil olarak tüm dünyada ilgileri üzerine çekmeye devam etmesiyle birlikte, iş hayatında markaların bilinirlik ve konumlandırılmalarında önemli bir araç 
haline gelmiştir (Yaman ve Acikgozoglu, 2016: 538). Bu nedenle de spor sponsorluğu, markaların hedeflerine ulaşmak için özellikle, bireysel sporcuların desteklendiği bireysel sporcu sponsorluğu; bireylerden oluşan ancak bireyin değil takımın desteklendiği spor takımı sponsorluğu ve spor temalı organizasyon/etkinlik sponsorluğu gibi üç farklı alt kategoride gerçekleştirilebilmektedir (Öztürk, 2013: 8).

Sosyal/Çevre Sponsorluğu: Markaların sosyal ve çevresel konulara duyarlılık göstermeleri insanların satın alma davranışlarında rol oynadığını göstermektedir. Bireyler markanın etik itibarını, sosyal faaliyetlerini göz önünde bulundurduğunu ve iki ürün aynı fiyat ve kaliteye sahipse, sosyal sorumluluğunu yerine getiren kurumun ürününü satın almayı tercih edeceklerini ifade etmektedirler (Kocabaş, 2016: 506). Dolayısıyla bireylerin, toplumsal ve çevresel sorunlar karşısında harekete geçen markalara karş1 olumlu bakış açısına sahip oldukları, bireylerden olumlu dönüşler aldıkları ve bu markalara yönelik bağl1lık (marka sadakati) geliştirdikleri söylenebilir (Silsüpür, 2020: 179). $\mathrm{Bu}$ durumun farkında olan markalar da, kamuoyunu etkileyerek tanıtımlarını yapmak ve olumlu imaj oluşturup sürdürmek amacıyla bireylerin duygularına ilişkin iletişim stratejileri gerçekleştirme aracı olarak sosyal sponsorluklara yönelmektedirler (Doğan ve Canöz, 2017: 67).

Eğitim Sponsorluğu: Okullar, yüksekokullar, araştırma enstitüleri, vakıflar, kütüphaneler, araştırma bursları, araştırma projeleri gibi çeşitli eğitim konularının desteklendiği bir sponsorluk çeşididir. Sponsor olan markalar gerek medya araçlarında, gerekse de proje ve araştırmalarda destekleyici kurum olarak isimlerinin geçmesiyle tanıtımlarını yapmaktadırlar (Okay, 2012: 217-221). Birçok kuruluş tarafından da gerçekleştirilen özellikle, eğitim sürecinde kendine nakdi olarak burs, eğitim masraflarını karşılama gibi destek sağlanmış olan bireylerin daha sonra markaya bir çalışan olarak kazandırıldıklarında markaya yönelik aidiyet duygusunun oluşacağı ve destekçi markaya fayda sağlayacağı söylenebilir (Gürbüz ve Tarhan, 2019: 545). Ayrıca markalar, toplumsal kalkınmanın anahtarı olan eğitime verdikleri destekle hem ülke refahının artmasına hem de markayı tecih edecek işgücünün eğitimli kişilerden oluşmasına katkı sağlayabilirler (Silsüpür, 2020: 73).

Kültür/Sanat Sponsorluğu: Opera, tiyatro, müzik, heykeltıraşlık, sahne sanatları, bale, operet, orkestra, koro, film ve televizyon programı, edebiyat, kişisel sanat/sanatçı, sergi, müze gibi çeşitli alanlarda genellikle mali açıdan yardımları, nadiren olmak kaydıyla da ürün/hizmet kapsamındaki destekleri içeren sponsorluk faaliyetleridir (Okay, 2013:184).

\section{Dijital Arenada Halkla İlişkiler Uygulaması Olarak Sponsorluk ve Web Sayfaları}

İçinde bulunduğumuz Dijital Çağ'da, web tarayıcılarının ve hizmet sunucularının gelişimi, insanların internette daha fazla dolaşmaları, markaların da dijital arenadaki önemli platformlardan birisi olan web sayfalarını daha zengin içerikli hale getirmesine (Doyle, 2008: 565) ve web sayfalarının daha etkin kullanılmasına imkan tanımıştır. 
Kurumsal web sayfaları; tüm paydaşların, hedef grupların ve tüm bireylerin marka/ kuruluş hakkında bilgi sahibi olabileceği sürekli açık olan bir vitrindir. İletişim kurulacak veya iletişim halinde olunan tüm birey ve kitleler açısından ilk izlenimin oluşacağı mecra çoğunlukla burasıdır. Dolayısıyla imajın ilk oluşacağı ve büyük olasılıkla da bu neticeye göre tutum ve davranışın şekilleneceği yer, kurumsal web sayfalarıdır (Kocabaş, 2020: $57)$.

Yeni iş ortamı, markaların sadece çevreye duyarlı birşekilde iş yapmalarını değil, aynı zamanda toplumsal kaygılar hakkındaki bakış açılarını halkla paylaşma sorumluluğunu da üstlenmelerini gerektirmektedir (Kim vd., 2010: 285). Bu noktada birçok marka, artan reklam maliyetleriyle birlikte fiyat dışı etkenlerle rekabet edebilmek, kalıcı ve güvenilir olmak, toplumu bilgilendirmek ve toplumsal sorumluluklarını yerine getirmek amaciyla sponsorluk faaliyetlerini gerçekleştirmektedir (Coşkun, 1999: 67). İnternet tabanlı bir mecra olan kurumsal web sayfaları, markaların sponsorlukları hakkında hem iç hem de dış paydaşlarına haber verme, duyurum ve bilgilendirme sağlamakta, paydaşların da marka birimleriyle iletişim kurmalarına olanak sunmaktadır (Sever, 2013: 95). Web sayfaları, bir markanın kendisini tanıtması açısından önemli bir araç olmakla birlikte, diğer kuruluş yayınlarından daha fazla tanıtım olanağı sunan ve dış dünyaya açılan pencere olarak görülmektedir (Sayımer, 2012:88). Markalar, kurumsal web sayfaları aracılığıyla hedef kitleleriyle iletişim ve ilişki kurmanın (Shin vd., 2015: 184) yanı sıra, ürettikleri çeşitli hizmetleri ve gerçekleştirdikleri sponsorluk faaliyetlerini bu platformda tanıtabilmektedir (Gürbüz ve Tarhan, 2019: 547). Ancak bu noktada web sayfasının halkla ilişkiler hedefleriyle uyumlu olarak, gösterilen (sunulan) sponsorluk faaliyetlerinin nedensellik bağlamında nerede ve nasıl sunulduğunu ortaya koyan bir içerik stratejisiyle tasarlanması yönetici ve marka açısından önem arz etmektedir (Chiou vd., 2010: 288). Ayrıca markaların halkla ilişkiler amaçlarını gerçekleştirmede kullandıkları sponsorluk faaliyetlerinin duyurulmasında önemli bir iletişim aracı olan web sayfaları, dikkat çekici içerik tasarımlarıyla da hedef kitleleri etkileyebilecektir.

Hızlı güncelleme yapabilme olanağı sunan web sayfaları, farklı uygulamalarla ziyaretçilerin web sitelerinde daha çok gezinip etkileşimde bulunmalarında önemli bir araç (Alikılıç, 2011: 66) olması nedeniyle sponsorluk faaliyetlerinin duyurulmasında da etkiye sahiptir. Bunun yanı sıra, hedef kitlenin istek, beklenti ve şikâyetlerinin hızlı bir şekilde markalara iletilmesine imkân sağlayan (Mavnacıŏlu, 2015: 10) web sayfaları, markaların sponsorluk faaliyetlerine yönelik geri bildirimleri öğrenmelerine, geleceğe yönelik hedeflerini gerçekleştirmelerine ve bunun sonucunda da reaktif ya da proaktif strateji geliştirmelerine imkân sunmaktadır (Güçdemir, 2015: 98).

Özetle, ziyaretçi çekmede önemli bir unsur olan kurumsal web sayfaları, geleneksel kitle iletişim araçları aracılığıyla ulaşılan daha pasif halktan daha aktif, bilgi arayan kitlelere erişmede kullanılmaktadır (Esrock ve Leichty, 1999. 456). Kurumsal web sayfaları, markaların bilgi arayışındaki aktif kitleleri özellikle de sponsorluk gibi kendi faaliyetleri hakkında bilgilendirerek markanın imajına olumlu katkı sağlamak, tanınırlığını artırmak ve toplumda iyi niyet oluşturmak (Okay, 2012: 71-84) hedeflerine ulaşmada kullandıkları önemli bir araç olarak ön plana çıkmaktadır. Ayrıca web sayfaları, Dijital Çağ'ın yaşandığı bu dönemde markaların kullanımı açısından bilgi toplamak, çeşitli konularda kamuoyunu 
izlemek ve vatandaşları çeşitli konularda doğrudan diyaloga dâhil etmek için etkileşimli özelliğiyle de kullanılabilmektedir. Kurumsal web sayfaları aynı anda birden fazla kişinin isteklerini ve ihtiyaçlarını karşılamayı hedefleyen birçok bölüme sahip olması nedeniyle (Esrock ve Leichty, 1999: 457), markaların sponsorluk faaliyetlerine ilişkin geri dönüşler almasına yardımcı olmakta ve markaların rakiplerine göre daha olumlu algılanmasına katkı sağlamaktadır.

\section{Araştırmanın Yöntemi}

Çalışma, Brand Finance “2021 Türkiye'nin En Değerli Markaları” sıralamasındaki ilk 10 markanın web sayfalarının içerik analizi yöntemiyle incelenmesinden oluşmaktadır. Bu amaçla Türkiye'nin En Değerli Markalar sıralamasındaki ilk 10 markanın sponsorluk çalışmalarına verdikleri önemi ortaya koyabilmek amacıyla web sayfalarında "Nasıl? Nerede? Ne biçimde?" sponsorluk faaliyetlerine yer verdikleri araştırılmıştır. Türkiye'nin En Değerli Markalarını belirlemek için Brand Finance' $1 n^{1}$ her yıl yayımladı ğı rapor dikkate alınmış, en değerli ilk 10 marka incelenmiş ve bu markaların kurumsal web sayfaları üzerinden sponsorluk mesajlarını tespit etmek amacıyla 02.07.2021-16.07.2021 tarihleri arasında içerik analizi yöntemi kullanılmıştır. Çalışmanın evreni Brand Finance'ın yayımladığı rapordaki 2021 yılı Türkiye'nin En Değerli Markaları, örneklemi ise Türkiye'nin En Değerli İlk 10 Markası olarak belirlenmiştir. Dolayısıyla bu çalışmanın amac1, Brand Finance'1n 2021 y1lı raporu doğrultusunda, Türkiye'nin En Değerli Markalarının sponsorluk mesajlarının kurumsal web sayfaları üzerinden incelemektir.

Tablo 1. Brand Finance 'ın Değerlendirdiği Türkiye'nin En Dĕgerli İlk 10 Markası

\begin{tabular}{|c|c|c|c|c|}
\hline $\begin{array}{l}2021 \\
\text { Sirası }\end{array}$ & Marka & $\begin{array}{l}2021 \\
\text { Marka } \\
\text { Değeri (\$) }\end{array}$ & $\begin{array}{l}\text { Marka } \\
\text { Değerindeki } \\
\text { Değişiklik (\$) }\end{array}$ & $\begin{array}{l}2020 \\
\text { Sirası }\end{array}$ \\
\hline 1 & Türk Hava Yolları (THY) & 1,605 & $-18.7 \%$ & 1 \\
\hline 2 & Arçelik & 1.585 & $+24.6 \%$ & 5 \\
\hline 3 & Türkiye İş Bankası & 1.193 & $+25.3 \%$ & 8 \\
\hline 4 & Garanti BBVA & 1,190 & $-22.6 \%$ & 3 \\
\hline 5 & Turkcell & 1,061 & $-22.1 \%$ & 4 \\
\hline 6 & Ziraat Bankası & 952 & $-41.0 \%$ & 2 \\
\hline 7 & Akbank & 917 & $-8.1 \%$ & 7 \\
\hline 8 & Yap1 Kredi & 836 & $-4.5 \%$ & 9 \\
\hline 9 & Türk Telekom & 789 & $-27.4 \%$ & 6 \\
\hline 10 & Ford Otosan & 787 & $-10.1 \%$ & 10 \\
\hline
\end{tabular}

Kaynak: https://brandirectory.com

Çalışmada, markaların kurumsal web sayfalarında yer alan sponsorlukla ilgili mesajların paylaşımını analiz etmek için çeşitli araştırmacıların sınıflandırmalarından

1 Brand Finance, dünyanın en değerli markalarını analiz edip belirleyen, markaların değerlerini her yıl yayımladıkları raporla ortaya koyan bir kuruluştur (http://brandfinance.com, 2021). 
yararlanılmıştır. $\mathrm{Bu}$ amaçla, sponsorlukla ilgili linklerin web sayfalarındaki konumu ("ana sayfada sponsorluk başlığı altında link", "alt sayfada sponsorluk başlığı altında link", "sponsorluk başlıklı link yok") ve sponsorlukla ilgili mesajların web sayfalarında iletilme biçimlerine (metin, görsel ve yazılı materyal, görsel ve işitsel materyal, rapor/ yıllık rapor, basın bülteni, kuruluş yayını) ilişkin sorgulamada Esrock ve Leichty'in (1998) sinıflandırmasından; sponsorlukla ilgili düzeylerin belirlenmesi ve markaların hangi sponsorluk düzeylerinde bulunduğunu tespit etmek için Lucas'ın (2015) “ana sponsor" ve "yan sponsor" sınıflandırmasından yararlanılmıştır. Yine kodlama cetveli oluşturulurken sponsorluk uygulama alanlarıyla ilgili yerli ve yabancı araştırmacıların (Oliver, 2004: Lucas, 2015; Okay, 2013: Peltekoğlu, 2014: Akkaya, 2016: Gürbüz ve Tarhan, 2019) çalışmalarına ve ilgili literatüre bakıldığında, sponsorluk çeşitlerinin "spor sponsorluğu", sosyal/çevre sponsorluğu", eğitim sponsorluğu" ve kültür/sanat sponsorluğu" olarak kategorize edildiği görülmektedir. Bu bakımdan çalışmada sponsorluk çeşitleriyle ilgili bu dört sinıflandırma kullanılacaktır.

Çalışmada, markaların sponsorluk mesajlarının kurumsal web sayfasının neresinde yer verildiği, markaların kurumsal web sayfalarında sponsorluğun hangi uygulama alanlarıyla ilgili mesajlar sunulduğu, mesajların hangi iletişim biçimiyle sunulduğu gibi bilgiler, 2021 yılı Türkiye'nin En değerli ilk 10 markası özelinde analiz edilerek sunulmuştur. Dolayısıyla çalışmada aşağıdaki sorulara yanıt aranacaktır:

Araştırma Sorusu 1: Markalar kurumsal web sayfalarında sponsorluk linkine yer vermekte midir?

Araştırma Sorusu 2: Markaların kurumsal web sayfalarında sponsorluk mesajlarına yönelik bilgiler web sayfasının neresinde yer almaktadır?

Araştırma Sorusu 3: Markaların kurumsal web sayfalarındaki sponsorluk mesajları daha çok hangi sponsorluk alanıyla ilgilidir?

Araştırma Sorusu 4: Markaların kurumsal web sayfalarında yer alan sponsorluk mesajları daha çok hangi sponsorluk düzeyiyle ilgilidir?

Araştırma Sorusu 5: Markalar kurumsal web sayfalarında sponsorluğa yönelik mesajları hangi iletişim biçimiyle duyurmaktadır?

\section{Bulgular}

Çalışmanın bu bölümünde, yapılan analizler sonucunda Türkiye'nin En Değerli ilk 10 markasının kurumsal web sayfalarında sponsorluk mesajlarının görünümüne ilişkin elde edilen bulgulara yer verilmiştir.

\section{Markaların Sektörlere Göre Dă̆ılımı}

Türkiye'nin en değerli markaları evreninden belirlenen örneklem grubuna bakıldığında; 5 (\%50) markanın bankacılık, 2 (\%20) markanın telekomünikasyon ve 1'er markanın ise havayolu (\%10), otomotiv (\%10) ve dayanıklı tüketim (\%10) sektöründe faaliyet gösterdiği görülmektedir (Bkz. Tablo 2). 
Tablo 2. Örneklem Belirlenen Markaların Sektörlere Göre Dă̆ılımı

\begin{tabular}{|l|l|l|}
\hline Sektör & Sayı (n) & Yüzde (\%) \\
\hline Banka & 5 & 50 \\
\hline Telekomünikasyon & 2 & 20 \\
\hline Havayolu & 1 & 10 \\
\hline Otomotiv & 1 & 10 \\
\hline Dayanıkl Tüketim & 1 & 10 \\
\hline Toplam & $\mathbf{1 0}$ & $\mathbf{1 0 0}$ \\
\hline
\end{tabular}

\section{Kurumsal Web Sayfalarında Sponsorluk Linklerine Yer Verme Durumu}

Türkiye'nin en değerli ilk 10 markasının kurumsal web sayfaları, markaların sponsorluk linkine yer verip vermediklerine göre analiz edilmiştir. Buna göre, markaların \%40.0'ının (THY, Garanti BBVA, Turkcell, Türk Telekom) sponsorluk linkine yer verdikleri, \%60.0'ının (Arçelik, Türkiye İş Bankası, Ziraat Bankası, Akbank, Yapı Kredi ve Ford Otosan) sponsorluk linkine yer vermedikleri görülmektedir (Bkz. Tablo 3) . Ortaya çıkan bu sonuca göre, ilk on marka sıralaması içerisinde bulunan markaların çoğunluğunun (\%60.0'ının) web sayfalarında sponsorluk linkine yer vermedikleri söylenebilir.

Tablo 3. Web Sayfalarında Sponsorluk Linklerine Yer Verme Durumu

\begin{tabular}{|l|l|}
\hline Markalar & $\begin{array}{l}\text { Sponsorluk } \\
\text { Mesajlarına Yönelik Link }\end{array}$ \\
\hline Türk Hava Yolları & Var \\
\hline Arçelik & Yok \\
\hline Türkiye İş Bankası & Yok \\
\hline Garanti BBVA & Var \\
\hline Turkcell & Var \\
\hline Ziraat Bankası & Yok \\
\hline Akbank & Yok \\
\hline Yapı Kredi & Yok \\
\hline Türk Telekom & Var \\
\hline Ford Otosan & Yok \\
\hline
\end{tabular}

Kurumsal web sayfalarında sponsorluk linki olmayan fakat sponsorluk faaliyetlerinde bulunan markaların sponsorluk mesajları incelendiğinde; Arçelik, sponsorlukla ilgili mesajlarını hem Arçelik web sayfasında yer alan "Kurumsal" linkinden hem de ayrı bir web sayfası olan ve birbirine entegre çalışan "Arçelik A.Ş." web sayfasının "Sorumluluklar" ana başlığı altındaki "Toplumsal Sorumluluklar" başlı̆ğ içinde "Kültür, Sanat ve Spora Destek" linkinden paylaştığı; Türkiye İş Bankası, ana sayfada yer alan "Bankamızı Tanıyın" linki altında "Kurumsal Sosyal Sorumluluk" linkiyle paylaştığı; Ziraat Bankası, ana sayfada "Bankamız" linki içinde "Kültür-Sanat" linkiyle; Akbank, 
ayrı bir web sayfa olan "Akbank Sanat"; Yapı Kredi, web sayfasının altında bulunan "Yapı Kredi Hakkında" linki içinde "Kültür ve Sanat" linkiyle ve Ford Otosan ise web sayfası altında bulunan "Ford Hakkında" linkinin içinde "Ford Performance Türkiye" ve Ford Otosan'ın resmi blogu olan "FordBlog" aracılığıyla paylaştığı tespit edilmiştir. Buna göre, markaların gerçekleştirdikleri sponsorluk faaliyetlerine ilişkin mesaj linklerine doğrudan bir "sponsorluk" başlı̆̆ı altında değil de, farklı başlıklar altında yer verdikleri söylenebilir.

\section{Sponsorlukla İlgili Linklerin Web Sayfalarındaki Konumu}

Türkiye'nin en değerli ilk 10 markasının sponsorlukla ilgili mesajlarını web sayfalarının neresinde paylaştığına bakıldığında; markaların \%60.0'ının (Arçelik, Türkiye İş Bankası, Ziraat Bankası, Akbank, Yapı Kredi ve Ford Otosan) doğrudan sponsorluk linkinin olmadığı, \%30.0'unun (THY'nin, Turkcell'in ve Türk Telekom) alt sayfada sponsorluk başlığı altında linkinin olduğu, \%10.0'unun (Garanti BBVA) ise ana sayfada sponsorluk başlığı altında linkin bulunduğu tespit edilmiştir (Bkz. Tablo 4). Bu verilere göre, markaların çoğunluğunun (\%60.0'ının) doğrudan sponsorluk linkine sahip olmadıkları, sponsorluk linki olanların (\%40.0'ının) ise sayfanın değişik yerlerinde yer verdikleri söylenebilir.

Tablo 4. Sponsorlukla İlgili Linklerin Web Sayfalarındaki Konumu

\begin{tabular}{|l|l|l|l|l|l|l|l|l|l|l|}
\hline $\begin{array}{l}\text { Sponsorlukla } \\
\text { İgili Linkler }\end{array}$ & THY & Arçelik & $\begin{array}{l}\text { Türkiye } \\
\text { İş Bankası }\end{array}$ & $\begin{array}{l}\text { Garanti } \\
\text { BBVA }\end{array}$ & Turkcell & $\begin{array}{l}\text { Ziraat } \\
\text { Bankası }\end{array}$ & Akbank & $\begin{array}{l}\text { Yapı } \\
\text { Kredi }\end{array}$ & $\begin{array}{l}\text { Türk } \\
\text { Telekom }\end{array}$ & $\begin{array}{l}\text { Ford } \\
\text { Otosan }\end{array}$ \\
\hline $\begin{array}{l}\text { Ana sayfada } \\
\text { sponsorluk } \\
\text { başlığı altında } \\
\text { link }\end{array}$ & & & & & & & & & \\
\hline $\begin{array}{l}\text { Alt sayfada } \\
\text { sponsorluk } \\
\text { başlığ altında } \\
\text { link }\end{array}$ & $\mathrm{X}$ & & & & & & & & & \\
\hline $\begin{array}{l}\text { Sponsorluk } \\
\text { başlıklı link } \\
\text { yok }\end{array}$ & & $\mathrm{X}$ & $\mathrm{X}$ & & & $\mathrm{X}$ & $\mathrm{X}$ & $\mathrm{X}$ & & $\mathrm{X}$ \\
\hline
\end{tabular}

Markaların sponsorluk mesajlarını kurumsal web sayfalarının neresinde paylaştıklarına detaylı bakıldığında; Garanti BBVA ana sayfada bulunan "Hakkımızda" başlığı içinde bulunan "Kurumsal İletişim" linki içinde paylaştığı; Turkcell'in alt sayfada sponsorluk linki olmasına rağmen sponsorluk linkine tıklandığında "Toplumsal Sorumluluk ve Sponsorluk" başlığının açıldığı ve burada sosyal sorumluluk faaliyetlerini de paylaştı̆̆ ve karışıklığa yol açtı̆̆ , Türk Telekom'un alt sayfada "Hakkımızda" linkine tıklandığı zaman görülen "sponsorluk" linkinin herhangi bir işlevi olmadığı, açıklama ve faaliyetlerin paylaşılmadığı, sadece sponsorluk talepleri için çevrimiçi (online) başvuru alındığı; bunun yanında web sayfasının altında bulunan "Medya Merkezi" linki içinde "Basın Bültenleri ve Görseller" linki içinde sponsorluk paylaşımlarını yaptığı; Arçelik'in sponsorlukla ilgili mesajlarını hem "Arçelik" hem de ayrı bir web sayfası olan "Arçelik 
A.Ş." den "Sorumluluklar" başlığı altında "Toplumsal Sorumluluk" içinde yer verdiği; Türkiye İş Bankası, Ziraat Bankası, Akbank, Yap1 Kredi, Ford Otosan'ın sponsorluk başlıklı linklerinin olmadığ 1 tespit edilmiştir. Burada en göze çarpan markanın THY olduğu ve alt sayfada sponsorlukla ilgili bir linkin bulunduğu ve markanın sponsor olduğu alanları da kategorize ederek kurumsal web sayfasında paylaşması dikkat çekmektedir. Buna göre, THY dışındaki markaların halkla ilişkiler uygulaması olan "Sponsorluk", "Sosyal Sorumluluk" ve marka ve kurum arasındaki her türlü iletişimde ihtiyaç duyulan "Kurumsal İletişim” kavramlarını karıştırdığı, mesajlarını yanlış uygulamalar içerisinde paylaştıkları veya uygulamaları birleştirerek etkili bir web sayfası kullanımı gerçekleştiremedikleri ve hedef kitlelerin algılarını yanlış yönlendirdikleri ifade edilebilir.

\section{Konularına Göre Sponsorluk Alanları}

Türkiye'nin en değerli markaların kurumsal web sayfalarında ilgili literatür kapsamında kategorileştirilen sponsorluk türleri analiz edilmiş ve markaların hangi sponsorluk türünde daha çok uygulama yaptığı belirlenmiştir (Bkz. Tablo 5).

Tablo 5. Konularına Göre Sponsorluk Alanlarının Web Sayfalarındaki Dă̆ılımı

\begin{tabular}{|c|c|c|c|c|c|c|c|c|c|c|c|c|c|c|c|c|c|c|c|c|c|c|}
\hline \multirow{2}{*}{$\begin{array}{l}\text { Sponsorluk } \\
\text { Çeşitleri }\end{array}$} & \multicolumn{2}{|c|}{ THY } & \multicolumn{2}{|c|}{ Arçelik } & \multicolumn{2}{|c|}{$\begin{array}{l}\text { Türkiye } \\
\text { İş } \\
\text { Bankası }\end{array}$} & \multicolumn{2}{|c|}{$\begin{array}{l}\text { Garanti } \\
\text { BBVA }\end{array}$} & \multicolumn{2}{|c|}{ Turkcell } & \multicolumn{2}{|c|}{$\begin{array}{l}\text { Ziraat } \\
\text { Bankası }\end{array}$} & \multicolumn{2}{|c|}{ Akbank } & \multicolumn{2}{|c|}{$\begin{array}{l}\text { Yapı } \\
\text { Kredi }\end{array}$} & \multicolumn{2}{|c|}{$\begin{array}{l}\text { Türk } \\
\text { Telekom }\end{array}$} & \multicolumn{2}{|c|}{$\begin{array}{l}\text { Ford } \\
\text { Otosan }\end{array}$} & \multicolumn{2}{|c|}{ Toplam } \\
\hline & $\mathbf{n}$ & $\%$ & $\mathbf{n}$ & $\%$ & n & $\%$ & $\mathbf{n}$ & $\%$ & $\mathbf{n}$ & $\%$ & $\mathbf{n}$ & $\%$ & $\mathbf{n}$ & $\%$ & $\mathbf{n}$ & $\%$ & $\mathbf{n}$ & $\%$ & $\mathbf{n}$ & $\%$ & \begin{tabular}{|l|}
$\mathbf{n}$ \\
\end{tabular} & $\%$ \\
\hline Spor & 14 & 100 & 14 & 56 & - & - & 3 & 33 & 30 & 94 & 1 & 3 & - & - & - & - & 9 & 82 & 6 & 100 & 77 & 34 \\
\hline Sosyal/Çevre & - & - & - & - & - & - & - & - & - & - & - & - & - & - & - & - & - & - & - & - & - & - \\
\hline Eğitim & - & - & - & - & 4 & 29 & - & - & - & - & - & - & - & - & - & - & 2 & 18 & - & - & 6 & 3 \\
\hline Kültür/Sanat & - & - & 11 & 44 & 10 & 71 & 6 & 67 & 2 & 6 & 28 & 97 & 77 & 100 & 6 & 100 & - & - & - & - & 140 & 63 \\
\hline Toplam & 14 & 100 & 25 & 100 & 14 & 100 & 9 & 100 & 32 & 100 & 29 & 100 & 77 & 100 & 6 & 100 & 11 & 100 & 6 & 100 & 223 & 100 \\
\hline
\end{tabular}

Markaların sponsorluk alanlarına yönelik uygulamalarına bakıldığında, her markanın bir alanda sponsorluk faaliyetine ağırlık verdikleri anlaşılmaktadır. Her markanın gerçekleştirdiği sponsorluk türleri incelendiğinde; THY mesaj paylaşımlarının tamamın $\% 100.0$ ile (14) spor sponsorluğunda; Arçelik \%56.0 ile (14) spor, \%44.0 ile (11) kültür/sanat sponsorluğunda; Türkiye İş Bankas1 \%71.0 ile (10) kültür/sanat, \%29.0 ile (4) eğitim sponsorluğunda; Garanti BBVA \%67.0 ile (6) kültür sanat, \%33.0 ile (3) spor sponsorluğunda; Turkcell \%94.0 ile (30) spor, \%6.0 ile (2) kültür/sanat sponsorluğunda; Ziraat Bankası \%97.0 ile (28) kültür/sanat, \%12.0 ile (1) spor sponsorluğunda; Akbank \%100.0 ile (77) yalnızca kültür/sanat sponsorluğunda; Yapı Kredi \%100.0 ile (6) kültür/ sanat sponsorluğunda, Türk Telekom \%82.0 ile (9) spor, \%18.0 ile (2) mesajla eğitim sponsorluğunda ve Ford Otosan \%100.0 ile (6) spor sponsorluğunda bulunduğu tespit edilmiştir.

Markaların sponsorluk faaliyet türlerine ve web sayfalarından paylaşımlarına bakıldığında; toplam 223 sponsorluk mesajı paylaştıkları, \%63.0 ile (140) en fazla paylaşımın kültür/sanat, \%34.0 ile (77) spor ve \%3.0 (6) paylaşımla eğitim sponsorluğu 
gerçekleştirdikleri anlaşılmaktadır. Sosyal/çevre sponsorluğu alanında ise hiçbir markanın sponsorluk faaliyeti gerçekleştirmediği görülmektedir.

\section{Sponsorluk Alanlarına Yönelik Destek Düzeyleri}

Türkiye'nin en değerli ilk 10 markasının sponsorluk destek düzeyleriyle ilgili dağılımı Tablo 6' da belirtilmiştir.

Tablo 6. Sponsorluk Destek Düzeylerinin Web Sayfalarındaki Dă̆ılımı

\begin{tabular}{|c|c|c|c|c|c|c|c|c|c|c|c|c|c|c|c|c|c|c|c|c|c|c|}
\hline \multirow{2}{*}{$\begin{array}{c}\text { Sponsor- } \\
\text { luk Destek } \\
\text { Düzeyleri }\end{array}$} & \multicolumn{2}{|c|}{ THY } & \multicolumn{2}{|c|}{ Arçelik } & \multicolumn{2}{|c|}{$\begin{array}{c}\text { Türkiye İş } \\
\text { Bankası }\end{array}$} & \multicolumn{2}{|c|}{$\begin{array}{c}\text { Garanti } \\
\text { BBVA }\end{array}$} & \multicolumn{2}{|c|}{ Turkcell } & \multicolumn{2}{|c|}{$\begin{array}{c}\text { Ziraat } \\
\text { Bankası }\end{array}$} & \multicolumn{2}{|c|}{ Akbank } & \multicolumn{2}{|c|}{$\begin{array}{c}\text { Yapı } \\
\text { Kredi }\end{array}$} & \multicolumn{2}{|c|}{$\begin{array}{c}\text { Türk } \\
\text { Telekom }\end{array}$} & \multicolumn{2}{|c|}{$\begin{array}{c}\text { Ford } \\
\text { Otosan }\end{array}$} & \multicolumn{2}{|c|}{ Toplam } \\
\hline & $\mathbf{n}$ & $\%$ & $\mathbf{n}$ & $\%$ & n & $\%$ & $\mathbf{n}$ & $\%$ & n & $\%$ & $\mathbf{n}$ & $\%$ & $\mathbf{n}$ & $\%$ & $\mathbf{n}$ & $\%$ & $\mathbf{n}$ & $\%$ & $\mathbf{n}$ & $\%$ & $\mathbf{n}$ & $\%$ \\
\hline Ana Sponsor & 4 & 29 & 16 & 64 & & 7 & 3 & 33 & 2 & 6 & - & - & - & - & - & - & 1 & 9 & - & - & 27 & 12 \\
\hline Yan Sponsor & 6 & 42 & - & - & 4 & 29 & - & - & 2 & 6 & - & - & - & - & - & - & 1 & 9 & - & - & 13 & 6 \\
\hline Belirtilmemiş & 4 & 29 & 9 & 36 & 9 & 64 & 6 & 67 & 28 & 88 & 29 & 100 & 77 & 100 & 6 & 100 & 9 & 82 & 6 & 100 & 183 & 82 \\
\hline Toplam & 14 & 100 & 25 & 100 & 14 & 100 & 9 & 100 & 32 & 100 & 29 & 29 & 77 & 100 & 6 & 100 & 11 & 100 & 6 & 100 & 223 & 100 \\
\hline
\end{tabular}

Türkiye'nin en değerli markalarının gerçekleştirdikleri sponsorluk destek düzeylerine bakıldığında; THY \%29.0 ile (4) spor branşına ana sponsor, \%42.0 ile (6) branşa yan sponsor; Arçelik \%64.0 ile (16) ana sponsor; Türkiye İş Bankası \%7.0 ile (1) ana sponsor, \%29.0 ile (4) yan sponsor; Garanti BBVA \%33.0 ile (3) ana sponsor; Turkcell $\% 6.0$ ile (2) ana sponsor, \%6.0 ile (2) yan sponsor; Türk Telekom \%9.0'ar oranla (1) ana ve yan sponsor; Ziraat Bankası, Akbank, Yapı Kredi ve Ford Otosan'ın ise sağladıkları destek düzeylerinin belirtilmediği tespit edilmiştir. Farklı markaların kurumsal web sayfalarında farklı düzeyde sponsorluk desteği verdiklerine ilişkin bilgilere ulaşılırken, Ziraat Bankas1, Akbank, Yapı Kredi ve Ford Otosan'1n destek düzeylerine yönelik bilgilere yer vermeyerek etkili bir web sayfası kullanımı gerçekleştiremedikleri gibi sponsorluk faaliyetlerini gerçekleştirme amaçlarına ulaşmada bunun bir sorun olduğu söylenebilir.

\section{Sponsorlukla İlgili Mesajların İletilme Biçimleri}

Markaların web sayfaları sponsorluk mesajlarını iletme biçimleri bakımından incelendiğinde; THY mesajların \%100.0'ünde (14) görsel ve yazılı materyal; Arçelik mesajların \%100.0’ünde (25) metin; Türkiye İş Bankası mesajların \%64.0'ünde (9) metin, \%36.0'sinda (5) görsel ve yazılı materyal; Garanti BBVA mesajların \%100.0'ünde (9) metin, Turkcell mesajların \%94.0'ünde (30) görsel ve yazılı materyal, \%6.0'sında (2) görsel ve işitsel materyal, Ziraat Bankası mesajların \%93.0'ünde (27) görsel ve yazılı materyal, \% 7.0'sinde (2) görsel ve işitsel materyal; Akbank mesajların \%100.0'ünde (77) görsel ve yazılı materyal, Yapı Kredi mesajların \%100.0’ünde (6) görsel ve yazılı materyal, Türk Telekom mesajların \%100.0'ünde (11) basın bülteni ve Ford Otosan mesajların \%100.0'ünde (6) görsel ve yazılı materyal paylaşımında bulunduğu görülmüştür (Bkz. Tablo 7). 
Tablo 7. Sponsorluk Mesajlarının İletilme Biçimlerinin Web Sayfalarındaki Dă̆ılımı

\begin{tabular}{|c|c|c|c|c|c|c|c|c|c|c|c|c|c|c|c|c|c|c|c|c|c|c|}
\hline \multirow{2}{*}{$\begin{array}{l}\text { Sponsorluk } \\
\text { Çeşitleri }\end{array}$} & \multicolumn{2}{|c|}{ THY } & \multicolumn{2}{|c|}{ Arçelik } & \multicolumn{2}{|c|}{$\begin{array}{c}\text { Türkiye Iş } \\
\text { Bankası }\end{array}$} & \multicolumn{2}{|c|}{$\begin{array}{l}\text { Garanti } \\
\text { BBVA }\end{array}$} & \multicolumn{2}{|c|}{ Turkcell } & \multicolumn{2}{|c|}{$\begin{array}{c}\text { Ziraat } \\
\text { Bankası }\end{array}$} & \multicolumn{2}{|c|}{ Akbank } & \multicolumn{2}{|c|}{$\begin{array}{c}\text { Yapı } \\
\text { Kredi }\end{array}$} & \multicolumn{2}{|c|}{$\begin{array}{c}\text { Türk } \\
\text { Telekom }\end{array}$} & \multicolumn{2}{|c|}{$\begin{array}{c}\text { Ford } \\
\text { Otosan }\end{array}$} & \multicolumn{2}{|c|}{ Toplam } \\
\hline & $\mathrm{n}$ & $\%$ & $\mathbf{n}$ & $\%$ & na & $\%$ & $\mathbf{n}$ & $\%$ & $\mathrm{n}$ & $\%$ & na & $\%$ & $\mathbf{n}$ & $\%$ & $\mathrm{n}$ & $\%$ & n & $\%$ & n & $\%$ & $\mathbf{n}$ & $\%$ \\
\hline Metin & - & - & 25 & 100 & 9 & 64 & 9 & 100 & - & - & - & - & - & - & - & - & II & - & - & - & 43 & 19 \\
\hline Görsel ve & & & & & & & & & & & & & - & & & & & & & & & \\
\hline $\begin{array}{l}\text { Yazılı Ma- } \\
\text { teryal }\end{array}$ & 14 & 100 & - & - & 5 & 36 & - & - & 30 & 94 & 27 & 93 & 77 & 100 & 6 & 100 & - & - & 6 & 100 & 165 & 74 \\
\hline $\begin{array}{c}\text { Görsel ve } \\
\text { İşitsel Ma- } \\
\text { terval }\end{array}$ & - & - & - & - & - & - & - & - & 2 & 6 & 2 & 7 & - & - & - & - & - & - & - & - & 4 & 2 \\
\hline Rapor/Y1llik & - & - & - & - & - & - & - & - & - & - & - & - & - & - & - & - & - & - & - & - & - & - \\
\hline $\begin{array}{c}\text { Basin Bül- } \\
\text { teni }\end{array}$ & - & - & - & - & - & & - & - & - & - & - & - & - & - & - & - & 11 & 100 & - & - & 11 & 5 \\
\hline Kuruluş & - & - & - & - & - & - & - & - & - & - & - & - & - & - & - & - & - & - & - & - & - & - \\
\hline $\begin{array}{l}\text { Yayını } \\
\text { Toplam }\end{array}$ & 14 & 100 & 25 & 100 & 14 & 100 & 9 & 100 & 32 & 100 & 29 & 100 & 77 & 100 & 6 & 100 & 11 & 100 & 6 & 100 & 223 & 100 \\
\hline
\end{tabular}

Türkiye'nin en değerli markalarının toplam 223 sponsorluk mesajını iletme biçimleri değerlendirildiğinde; markaların \%74.0'ünün (165) en çok görsel ve yazılı materyal kullanarak paylaşımda bulunduğu, \%19.0'unun (43) metin ve \%5.0'inin (11) basın bülteni takip ettiği belirlenmiştir. Markaların sponsorluk mesajlarını \%2.0 ile (4) en az görsel ve işitsel materyal paylaşımıyla yaptığı tespit edilmiştir. Markaların web sayfalarından sponsorlukla ilgili mesajlarında rapor/yıllık rapor ve kuruluş yayını türlerinde ise hiç paylaşım yapmadığı görülmüştür.

\section{Sonuç}

Sponsorluk; desteklemek, himaye etmek gibi anlamlara gelmesinin ötesinde, bir markanın çeşitli organizasyon ve olaylara nakdi yardım yaparak markasını dolaylı olarak tanıtmasıdır. Markalar, halkla ilişkiler amaçlarını gerçekleştirmede kullandığı sponsorluk faaliyetleri hakkında bilgilendirme ve duyuruların yapılmasında, dijital bir mecra olarak kurumsal web sayfalarını kullanmaktadırlar. Günümüz markalarının çoğu, gerçekleştirdikleri sponsorluk faaliyetlerini dijital bir mecra olan kurumsal web sayfaları üzerinden daha hızlı ve kolay bir şekilde hedef kitlelere ulaştırıp duyurarak kurumsal hedeflere erişilmesine büyük katkı sağlamaktadırlar. Markalar, kurumsal web sayfalarından sponsorluk çalışmalarını paylaşarak hedef kitlelerin markaları tanımasına, marka bilinirlik düzeylerinin artmasına, markalara karşı sempati duymasına ve markaları tercih etmesine önemli katkılar sağlamaktadırlar. Bu bakımdan Türkiye'nin En Değerli ilk 10 markasının web sayfaları, sponsorluğa yönelik link kullanımı ve sponsorluk mesajları açısından araştırılmıştır.

Türkiye'nin En Değerli Markaları sıralamasında ilk 10'da yer alan markaların \%60.0'ının kurumsal web sayfasında "Sponsorluk" linkinin olmadığı sonucu dikkat çekicidir. Bunun yanı sıra, THY, Turkcell ve Türk Telekom'un "alt sayfada sponsorluk başlığı altında, Garanti BBVA’nın “ana sayfada sponsorluk başlığı altında” link bulundurduğu, diğer markaların ise sponsorluk başlıklı linklere yer vermediği görülmüsşür. Türkiye'nin en değerli ilk 10 markasının yarısından fazlasında hem sponsorluk linkinin 
olmaması hem de yalnızca Garanti BBVA'nın ana sayfada doğrudan sponsorluk başlığı altında link vermesi, markaların iletişim çalışmalarına yeteri kadar önem vermediğini ortaya koymakla birlikte, hedef kitlelerine de mesajlarını doğrudan iletmede geri kaldığını ve bu durumun da markalar hakkında olumsuz imaj oluşturabileceği söylenebilir. Ayrıca markaların sponsorluk mesajlarını, sponsorluk linki içinde çeşitli başlıklar altında paylaştıkları da tespit edilmiştir. Bu bağlamda yalnızca THY'nin doğrudan sponsorluk linki bulunduğu ve sponsorluk linki içinde sponsorluk dışında herhangi bir paylaşım yapmadığı ve amacına uygun mesaj paylaştığı belirlenmiştir. Bunun dışındaki markaların sponsorluk mesajlarını "Hakkımızda, Kurumsal İletişim, Toplumsal Sorumluluk ve Sponsorluk, Sponsorluk, Medya Merkezi, Basın Bülteni ve Görseller" gibi çeşitli başlıklar altında ya da link aracılığıyla paylaştığı tespit edilmiştir. Kurumsal web sayfasında sponsorluk linki olan markalar kıyaslandığında; THY dışındaki markaların halkla ilişkiler uygulaması olan "Sponsorluk", "Sosyal Sorumluluk" ve marka ve kurum arasındaki her türlü iletişimde ihtiyaç duyulan "Kurumsal İletişim" kavramlarını karıştırdığı ve mesajlarını yanlış uygulamalar içerisinde paylaştıkları söylenebilir. Diğer taraftan kurumsal web sayfalarında sponsorluk linki bulunmamasına rağmen sponsorluk faaliyetlerinde bulunan markaların mesajlarına bakıldığında, hedef kitlelere bir düzen içinde ve bir link oluşturarak sunamadıkları, yine "Sosyal Sorumluluk" ve "Sponsorluk” uygulamalarının karıştırıldığı anlaşılmaktadır. Örneğin "Ziraat Türkiye Kupası" Ziraat Bankası'nın uzun zamandır bilinen bir sponsorluk uygulaması olmasına rağmen web sayfasında görülmemektedir. Dolayısıyla, Türkiye'de hem marka değeri yüksek hem de tanınırlığ fazla olan bu markaların iletişim çalışmalarında profesyonelce davranamadıkları, etkili bir web sayfası yönetimi gerçekleştiremedikleri, her iki halkla ilişkiler uygulamasını da aynı çerçevede değerlendirdikleri ve bu durumun da hedef kitlelerin algısında olumsuzluğa yol açabileceği söylenebilir.

Çalışmanın dikkate değer sonuçlarından birisi de, markaların en çok destekledikleri sponsorluk alanlarının sırasıyla kültür/sanat, spor ve eğitim olduğudur. Markalar, sosyal/çevre sponsorluğu alanında hiçbir çalışma gerçekleştirmemekle birlikte, "Sosyal Sorumluluk" başlığı altında mesajlarını paylaştıkları görülmüştür. Sosyal/ çevre sponsorluklarının toplum nezdinde olumlu algı ve imaja sahip olmasına rağmen markaların bu alanda sponsorluk desteklerinin bulunmaması, kurumsal yönetim açısından önemli bir eksiklik olarak ortaya çıkmaktadır. Bunun yanı sıra, markaların sponsorluk destek düzeylerine bakıldığında, en fazla ana sponsor düzeyinde destek oldukları görülmekle beraber, çoğu markanın web sayfasında sponsorluk destek düzeyiyle ilgili herhangi bir mesaja yer vermeyerek sponsorluk faaliyetleriyle elde edilmek istenen sonuçların uzağında oldukları söylenebilir. Ayrıca markaların kurumsal web sayfalarını sponsorluk faaliyetlerini duyurmada kullanırken mesajlarını \%74.0 ile en çok görsel ve yazılı materyal olarak paylaştıkları, rapor/yıllık rapor ve kuruluş yayını türlerinde ise hiç paylaşımda bulunmadıkları dikkat çekicidir. Özellikle görsel içeriklerin daha dikkat çekici olduğu dijital ortamlarda, hedef kitlenin profili göz önünde bulundurularak sadece metinden ziyade, görsel ve metinin bir arada yer aldığı bir mesaj tasarımıyla sponsorluk faaliyetleri hakkında bilgi verilmesi amaçlanan hedefe erişilmesine yardımcı olacaktır.

Markaların öncelikle sponsorluk çalışmalarıyla ilgili mesajlarını kurumsal web sayfalarında sponsorluk linki altında paylaşmaları, sosyal sorumluluk ile sponsorluğu ayırt 
etmeleri, sponsorluk çeşitlerini kategorize etmeleri gerekmektedir. Markalar kullanıcı dostu ve karışıklığa yol açmayan bir web sayfası tasarlayarak sponsorlukla ilgili iletişim çalışmalarını hedef kitlelerle paylaşmalıdırlar. Markaların sponsorluk çalışmalarını hedef kitlelerle doğrudan paylaşma ve bilgi sağlama imkânı sunan dijital bir mecra olan web sayfalarından hızlı, güncellenebilir ve doğru bilgi paylaşması markalara olan güveni artıracak ve bu durum marka imajlarına olumlu katkı sağlayacaktır.

Bu çalışma Brand Finance'ın 2021 yılı raporu dikkate alınarak, Türkiye'nin En Değerli İlk 10 Markasının sponsorluk mesajlarının kurumsal web sayfalarında nasıl, ne biçimde ve nerede paylaştıklarını belirlemek amacıyla analiz edilmiştir. Çalışmada örneklem olarak sadece Türkiye'nin En Değerli İlk 10 Markası seçilmiş ve 02.07.202116.07.2021 tarihleri arasında incelenmiştir. Bu sebeple, diğer çalışmalarda örneklem genişletilebilir, daha geniş zaman aralığında araştırma yapılabilir, gelecek yıllarda çıkan raporun sonucuna göre markaların kurumsal web sayfaları tekrar incelebilir ve bu çalışmanın bulgularıyla kıyas edilebilir.

\section{Kaynaklar}

Akkaya, Yahya, (2016). "Sponsorluk Faaliyetlerinin Spora Etkilerinin İncelenmesi”, International Journal of Science Culture and Sport, 4, (3), s.811-820.

Alikılıç, Özlem Aşman, (2011). Halkla İlişkiler 2.0., Ankara: Efil Yayınevi.

Amoako, G. K., Dartey-Baah, K., Dzogbeuku, R. K., ve Kwesie, S., (2012). “The Effect of Sponsorship on Marketing Communication Performance: A Case Study of Airtel Ghana", African Journal of Marketing Management, 4, (2), s.65-79.

Ateşoğlu, İrfan, (2010). “Arkeolojik Kazı Sponsorluğunda İşletme Amaçlarının Belirlenmesi Üzerine Bir Araştırma”, Süleyman Demirel Üniversitesi Fen Edebiyat Fakültesi Sosyal Bilimler Dergisi, (22), s.179-190.

Aydede, Ceyda, (2002). Teorik ve Uygulamalı Halkla İlişkiler Kampanyaları, İstanbul: MediaCat Yayınları .

Canöz, K., ve Doğan, İ., (2015). "İmaj Oluşturma Aracı Olarak Sponsorluk”, Gümüşhane Üniversitesi İletişim Fakültesi Dergisi, 3, (2), s.19-39.

Chiou, W-C., Lin, C-C., ve Perng, C., (2010). "A Strategic Framework for Website Evaluation Based on A Review of the Literature from 1995-2006", Information \& Management, 47, s.282-290.

Cornwell, T. Bettina, (2020). Sponsorship in Marketing, New York: Routledge.

Coşkun, Hülya, (1999). "Bir Tutundurma Aracı Olarak Spor Sponsorluğu", Gazi Beden Eğitimi ve Spor Bilimleri Dergisi, 4, (3), s.63-68.

Doğan, İ., \& Canöz, K., (2017). "Sosyal Sponsorluk ve Kurumsal İmaj İlişkisi Üzerine Teorik Bir Çalışma”, Selçuk Üniversitesi Sosyal Bilimler Enstitüsü Dergisi, 37 , s.59-68. 
Doyle, Peter, (2008). Değer Temelli Pazarlama: Şirketinizi Büyütmek ve Hissedar Değeri Yaratmak İçin Pazarlama Stratejileri, (Çeviren: Gülfidan Barış), İstanbul: MediaCat Kitapları.

Esrock, S. L., ve Leichty, G. B., (1998). "Social Responsibility and Corporate Web Pages: Self-Presentation or Agenda-Setting?", Public Relations Review, 24, (3), s.305319.

Esrock, S. L., ve Leichty, G. B., (1999). "Corporate World Wide Web Pages: Serving the News Media and Other Publics", Journalism \& Mass Communication Quarterly, 76, (3), s.456-467.

Gardner, M. P., ve Shuman, P., (1988). "Sponsorships and Small Businesses", Journal of Small Business Management, 26, (4), s.44-52.

Güçdemir, Yeşim, (2015). Sanal Ortamda İletişim: Bir Halkla İlişkiler Perspektifi, İstanbul: Derin Yayınları.

Gürbüz, S., ve Tarhan, A., (2019). "Türkiye'nin İlk 500 Sanayi Kuruluşunun Sponsorluk Uygulamaları: Kurumsal Web Sayfaları Üzerine Bir Analiz”, Akdeniz Üniversitesi İletişim Fakültesi Dergisi, 31, s.537-559.

Javalgi, R. G., Traylor, M. B., Gross, A. C., ve Lampman, E., (1994). “Awareness of Sponsorship and Corporate Image: An Empirical Investigation", Journal of Advertising, $23,(4)$, s.47-58.

Kent, M. L., ve Taylor, M., (1998). "Building Dialogic Relationships Through the World Wide Web", Public Relations Review, 24, (3), s.321-334.

Kim, D., Nam, Y., ve Kang, S., (2010). "An analysis of Corporate Environmental Responsibility on the Global Corporate Web Sites and Their Dialogic Principles", Public Relations Review, 36, s.85-288.

Kocabaş, İsmail, (2016). "Social Responsibility Image in the Eyes of University Students: Selçuk University Sample", 2. International Congress on Media Studies, Antalya: Akdeniz Üniversitesi İletişim Fakültesi Yayınları, s.498-510.

Kocabaş, İsmail, (2020). Müşteri İlişkileri Yönetimi Perspektifinden Modern Tüketici, Konya: Eğitim Yayınevi.

Kürkçü, Duygu Dumanlı, (2015). "Sponsorluğun Marka Değeri Üzerine Etkisi”, Y1ldiz Journal of Art and Design, 2, (1), s.1-18.

Lucas, Christian, (2015). Sponsor and Country-Related Predictors of Sponsorship Effectiveness, Braunschweig: Springer Fachmedien Wiesbaden.

Mavnacioğlu, Korhan, (2015). Kurumsal İletişimde Sosyal Medya, İstanbul: Beta Yayınları.

MEB, (2011). Halkla İlişkiler ve Organizasyon Hizmetleri: Sponsorluk, Ankara: Milli Ĕ̆itim Bakanlığı. 
Okay, Aydemir, (2012). Sponsorluk, İstanbul : Der Yayınları.

Okay, Ayla, (2013). Kurum Kimliği, İstanbul: Derin Yayınları.

Oliver, Sandra M., (2004). Handbook of Corporate Communication and Public Relations, London: Routledge.

Öztürk, Sevgi Ayşe, (2013). "Spor Sponsorluğu: Kavram ve Özellikler”, Metin Argan (der.), Sporda Sponsorluk, Eskişehir: Aandolu Üniversitesi Yayınları, s.2-25. Dağıtım.

Peltekoğlu, Filiz Balta, (2014). Halkla İlişkiler Nedir?, İstanbul: Beta Basım

Renard, N., ve Sitz, L., (2011). "Maximising Sponsorship Opportunities: A Brand Model Approach", Journal of Product \& Brand Management, 20, (2), s.121-129.

Sayımer, İdil, (2012). Sanal Ortamda Halkla İlişkiler, İstanbul: Beta Yayınları.

Sever, Serdar, (2013). "Sponsorluk Duyurumu". Metin Argan (der.), Sporda Sponsorluk, Eskişehir: Anadolu Üniversitesi Yayınları, s.90-105.

Shin, W., Pang, A., ve Kim, H. J., (2015). "Building Relationship Trough Integrated Online Media: Global Organizations' Use of Brand Web Sites, Facebook and Twitter", Journal of Business and Technical Communication, 29, (2), s.184-221

Silsüpür, Özer, (2020). Kurumsal Sosyal Sorumluluk ve Marka İmaj1, Konya: Palet Yayınları.

Tekin, N., ve Eskicioğlu, Y. E., (2015). "Spor Sponsorluğu: Türk Hava Yollar1Türkiye Basketbol Federasyonu Örneği”, Spor Yönetimi ve Bilgi Teknolojileri Dergisi, $10,(1)$, s.14-36.

Yaman, F., ve Acikgozoglu, S., (2016). Sponsorship as A Promotion Tool: Rememberability of The Sport Sponsorship and It's Effect to Purchasing Behaviour, Global Business Research Congress, İstanbul: Press Academia Procedia, s.535-543.

https://brandfinance.com/who-we-are/our-story/, Erişim Tarihi: 25.06.2021.

https://brandirectory.com/download-report/brand-finance-turkey-100-2021-fullreport.pdf, Erişim Tarihi: 25.06.2021.

Araştırmacı Katkı Oranı: Araştırmacılar çalışmaya eşit oranda katkı sunmuştur.

Destekleyen Kurum/Kuruluşlar: Herhangi bir kurum/kuruluştan destek alınmamıştır.

Çıkar Çatışması: Herhangi bir çıkar çatışması bulunmamaktadır 